\title{
Response of Microbial Populations on the Creeping Bentgrass Phyllosphere to Periodic Fungicide Applications
}

\begin{abstract}
Joseph R. Doherty, Research Graduate Assistant II, Department of Plant Science and Landscape Architecture, University of Maryland, College Park 20742; Megan Botti-Marino, Graduate Research Assistant, Department of Plant, Soil, and Microbial Sciences, Michigan State University, East Lansing 48824; James P. Kerns, Associate Professor, and David F. Ritchie, Professor, Department of Entomology and Plant Pathology, North Carolina State University, Raleigh 27695; and Joseph A. Roberts, Assistant Professor, Department of Plant Science and Landscape Architecture, University of Maryland, College Park 20742
\end{abstract}

Accepted for publication 12 March 2017.

\section{Abstract}

Fungicides are frequently applied on golf course putting greens to combat the myriad of diseases that can affect them; however, it is unknown how these fungicides may affect microbial populations. Plant-associated microbial communities are intimately involved with plant development and soil biological processes. This two-year study was designed to evaluate the impact of five selected fungicides on culturable actinomycetes, fungi, general bacteria, and fluorescent pseudomonads residing in the turfgrass phyllosphere. Fungicides were applied at label rates on a 14-day interval. Four samples, consisting of five individual turf plants, were taken five days post- application. Samples were homogenized in $1 \mathrm{ml}$ sterile deionized water and serial diluted to $10^{-3}$ and $10^{-5}$. Each dilution was then plated onto four different media (actinomycete isolation agar, acidified potato dextrose agar, nutrient agar $+1 \%$ sucrose, and King's B) for enumeration of microbial populations. Fungicides had both positive and negative impacts on the culturable microbes tested, although population shifts across all treatments were observed with the prevailing weather conditions. These results show that while response to repeated fungicide application appears to be organism dependent, microbes are not completely removed from the environment.
There is a high demand for turfgrass managers to provide consumers with uniform playing surfaces that are maintained to the highest quality. However, plant-pathogenic fungi frequently make this a difficult task, given the myriad of diseases that decrease turf aesthetics and playability. This is particularly important in golf course putting greens, which are often considered the highest value area of a golf course. Cultural practices may provide some relief, but in many cases, unfavorable environmental conditions cause turfgrass managers to rely on pesticide applications to maintain turfgrass health and function. Many chemistries offer broad-spectrum control of many microbes, both pathogenic and nonpathogenic, through various biochemical modes of action (Alexander 1969; McCallan and Miller 1958). However, there are concerns about these chemistries altering the beneficial microflora of turfgrass ecosystems.

The preservation of the biodiversity of plant-associated microbial communities is necessary as they provide a wealth of benefits to plants including, but not limited to, cycling of organic matter, nutrient availability, and disease suppression (Alexander 1977). Previous research by White et al. (2012) suggests that association of tall fescue (Festuca arundinaceae L.) seedlings with diazotrophic bacteria such as Pantoea agglomerans and Pseudomonas ssp. allows for increased $\mathrm{N}$ uptake through oxidative nitrogen scavenging systems. Plantassociated microbial communities may build up to form suppressive soils, wherein there are communities antagonistic to multiple soil-borne pathogens (Mazzola 2002, 2004). Clarke et al. (2006) observed significantly less dollar spot in multiple fine fescues (Festuca spp.) positive for fungal endophytes as opposed to the same

Corresponding author: Joseph R. Doherty; E-mail: jdohert3@umd.edu

(C) 2017 The American Phytopathological Society fescues without endophytes. Some microorganisms, such as Pseudomonas fluorescens, can induce systemic resistance in a plant, which mimics systemic acquired resistance caused by pathogen infection (Pieterse et al. 1996; Van der Ent et al. 2009; van Loon et al. 1998).

There is concern over whether or not the fungicides applied to combat disease can lead to negative effects on nontarget microorganisms (Jacobsen and Hjelms $\varnothing$ 2014). Smiley and Craven (1979) observed that fungicide combinations applied to suppress fungi often stimulated bacteria and actinomycetes in the soil. In creeping bentgrass, applications of propiconazole and azoxystrobin lowered the populations of yeasts in the phyllosphere (Buck and Burpee 2002). In a similar study by Harman et al. (2006), fungicide applications did not impact the overall number of microbes on turfgrass foliage, but did impact the composition of microbial groups with specific fungicide chemistries; chlorothalonil applications resulted in higher populations of yeast and Penicillia while triadimefon applications favored Trichoderma growth. Additionally, there have been multiple studies looking at the effect of various pesticides on microbial communities, wherein the results indicate that the effect on microbial communities is dependent upon the pesticide used (Jacobsen and Hjelms $\varnothing$ 2014). With the wealth of fungicide chemistries available, it is possible that certain products may be impacting specific microbial groups that reside on turfgrass leaves. The recent rise in reports of bacterial disease in golf course putting greens has raised questions regarding the impact of fungicide applications on microbial communities (Giordano et al. 2012; Roberts et al. 2014). The objective of this research was to determine the impact of repeated fungicide applications across a growing season on culturable microbial groups residing in the turfgrass phyllosphere. 


\section{General Management Practices}

A 2-year field study was initiated in 2013 on creeping bentgrass [Agrostis stolonifera L. cv. 'A-1' (CBG)] turf grown on a sandbased root-zone, constructed according to USGA specifications at the Lake Wheeler Turfgrass Research Facility in Raleigh, NC. The site was established from seed as a monostand of CBG in 2006 and maintained as a golf course putting green from establishment. Turf was mowed 5 to 6 times per week using a Toro triplex mower (Greensmaster Model 3150-Q, The Toro Company, Bloomington, $\mathrm{MN}$ ) with a bench setting of 3.2 to $4.1 \mathrm{~mm}$; height of cut was increased during periods of heavy rainfall to avoid damage to the green surface. Prior to the initiation of treatments, nitrogen was applied at a total of $20 \mathrm{~kg} / \mathrm{ha}$ from March to April 2013 and $38 \mathrm{~kg} / \mathrm{ha}$ from February to April 2014. During treatment applications, nitrogen was applied biweekly as 5 to $10 \mathrm{~kg} / \mathrm{ha}$ to support plant growth. Elemental phosphorus and potassium were applied at 6 and $37 \mathrm{~kg} / \mathrm{ha}$ in 2013 and 44 and $75 \mathrm{~kg} / \mathrm{ha}$ in 2014, respectively. All fertilization was applied in a soluble form (i.e., 46-0-0, 25-5-18, 18$3-4$, and 25-6-12). The site was irrigated to prevent drought stress and support turfgrass growth. Alcohol ethoxates + polyethylene + polypropylene glycols (Cascade Plus, Precision Laboratories LLC, Waukegan, IL) and modified alkylated polyol (Revolution, Aquatrols, Paulsboro, NJ) were applied every 21 to 28 days throughout each growing season to maintain water infiltration. Except for chlorantraniliprole (Acelepryn, Syngenta Crop Protection, Greensboro, NC) applications on 24 June 2013 and 28 May 2014 to reduce insect pests, all maintenance pesticide applications were omitted from the experimental area for 7 months prior to first application.

\section{Fungicide Treatments}

Experimental plots $(0.9$ by $1.3 \mathrm{~m})$ were arranged with a $0.3-\mathrm{m}$ buffer in both years of study; and separate field plots were used each year. The buffer was inserted to prevent contamination from treatment applications. Fungicide treatments were: fluazinam (Secure, Syngenta Crop Protection) applied at $637 \mathrm{~g}$ a.i./ha;fluxapyroxad (Xzemplar, BASF Corp., Raleigh, NC) applied at $244 \mathrm{~g}$ a.i./ha; chlorothalonil (Daconil Ultrex, Syngenta Crop Protection) applied at 8056 g a.i./ha; fosetyl-aluminum (Chipco Signature, Bayer Environmental Science, Research Triangle Park, NC) applied at $9783 \mathrm{~g}$ a.i./ha; pyraclostrobin (Insignia, BASF Corp.) applied at $488 \mathrm{~g}$ a.i./ha (2014 Only); and no fungicide. All treatments, starting 5 June 2013 and 22 May 2014, were applied every 14 days using a $\mathrm{CO}_{2}$-pressurized sprayer to deliver the appropriate rate of 816 liter $\mathrm{H}_{2} \mathrm{O} /$ ha.

\section{Microbial Community Extraction}

To explore fungicide effects on the phyllosphere microbial community, four completely randomized samples were extracted from individual treatments, five days after each application. Samples were taken using a $0.9-\mathrm{m} \times 1.3-\mathrm{m}$ grid containing $1710.05-\mathrm{m} \times 0.05-\mathrm{m}$ sampling locations, and a random-number generator for selecting grid locations within each plot. Using sterilized forceps, phyllosphere samples were taken by removing five individual turf plants from the putting green surface, removing root and senescent material, placing in a preweighed $1.5-\mathrm{ml}$ microcentrifuge tube, and transporting on ice from the field to laboratory to limit microbial activity prior to analysis.

Once samples were transported to the laboratory, tubes were weighed again to obtain the weight of the plant material in each sample. In order to isolate microbes inhabiting the plant material, $1 \mathrm{ml}$ of sterile deionized water (DI water) was added to each sample along with two microcentrifuge capfuls of 450 to $600-\mu \mathrm{m}$ glass beads (Acros Organics) prior to pulverizing samples using a plastic pestle. The resulting suspension was vortexed for $10 \mathrm{~s}$ and diluted in sterile DI water in a 10 -fold dilution series to obtain $10^{-3}$ and $10^{-5}$ dilutions. Once diluted, $10 \mu$ l of each dilution were plated onto four different isolation media including Actinomycete isolation agar (VWR, Radnor, PA), acidified potato dextrose agar (pH 4.5) (Becton, Dickinson, and Co., Franklin Lakes, NJ), nutrient agar (Becton, Dickinson, and Co.) $+1 \%$ sucrose, and King's Medium B (Becton, Dickinson, and Co.). All four media were included to isolate different microorganisms including actinomycetes, general bacteria, fungi, and fluorescent pseudomonads, respectively. Using a flame-sterilized bent glass rod, the $10 \mu \mathrm{l}$ was lawned across each plate. This process was repeated for all replicate samples comprising each fungicide treatment for a total of 160 plates each sampling period in year one of the trial, and 192 plates each sampling period in year two of the trial. All plates were maintained in a dark box at room temperature $\left(27^{\circ} \mathrm{C}\right)$.

\section{Data Collection and Analysis}

Microbial growth was quantified by visual counts of colony forming units (CFUs) at 48 and $168 \mathrm{~h}$ after plating. An ultraviolet light source in a dark room was required to quantify fluorescent pseudomonads and all plate quantifications were normalized to the weight of the tissue sampled to discern the CFUs per gram of turf tissue. Data for individual rating dates and cumulative changes over the growing season were analyzed by analysis of variance using the generalized linear model mixed procedure in Statistical Analysis Software 9.4 (SAS Institute Inc., Cary, NC). Mean separations were obtained using Tukey-Kramer HSD at the 0.05 level.

\section{Effects of Repeated Fungicide Applications}

Actinomycetes. Populations of actinomycetes were higher in response to fluazinam applications in 2013 when compared with all other treatments and the nontreated control (Fig. 1). In 2014, applications of fluazinam, chlorothalonil, and fosetyl-Al all decreased actinomycete populations compared with the nontreated control. Actinomycete populations in 2014 were highly variable prior to 7 July, but following 7 July the variability in population levels decreased (Fig. 2).

Fungi. All fungicidal effects on fungi dissipated by the final sample date in 2013 (Table 1), with populations rebounding close to pretreatment levels (data not shown). Chlorothalonil and pyraclostrobin significantly decreased fungal populations in 2014 when compared with the nontreated control (Fig. 1). On individual sample dates in 2014, fungi exhibited variable responses to fungicide applications (Table 2). The fosetyl-Al treatment had higher populations of fungi when compared with the nontreated control on the first two dates, yet on subsequent dates, the nontreated control had higher populations (Table 2). All other treatments on individual samples dates in 2014 had populations lower than the nontreated control (Table 2).

Bacteria. Fungicides did not significantly impact general bacterial populations in 2013 when averaged across the growing season. However, general bacteria populations appeared lower, though not statistically significant, as a result of fosetyl-Al applications (Fig. 1). General bacteria exhibited a lag response to fungicide applications on individual sample dates in 2013, with differences appearing at the second rating date (Table 1). Applications of fluazinam reduced populations of general bacteria in 2014 (Fig. 1). Additionally in 2014, general bacterial populations observed variable effects from fungicide treatments on individual sampling dates (Fig. 2; Table 2). Of the differences observed, 


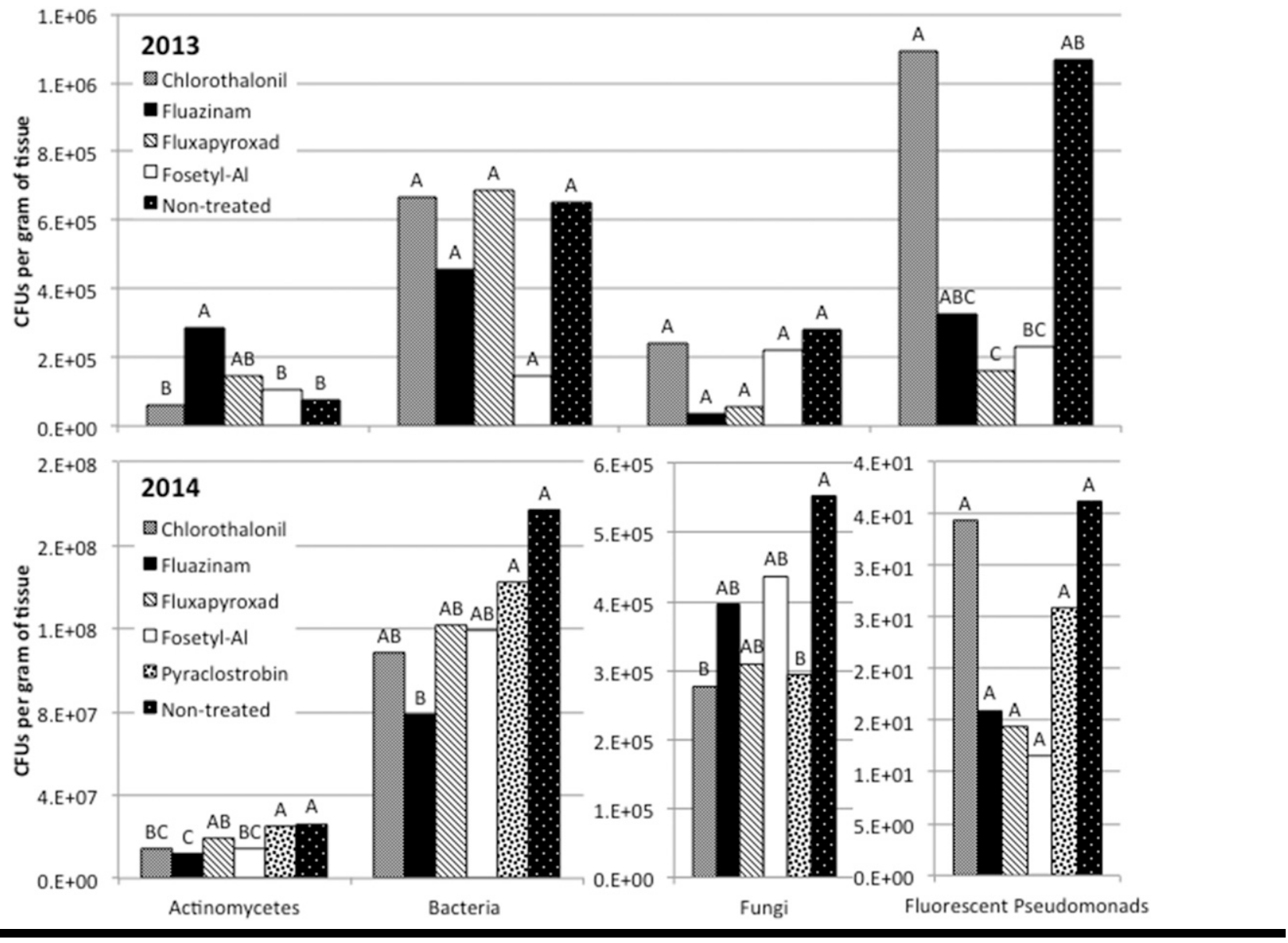

\section{FIGURE 1}

Impact of repeated fungicide applications on individual microbial groups sampled in a creeping bentgrass putting green across 2013 (upper) and 2014 (lower). For each microbial group values represent cumulative means with letter designations indicating significant differences at the 0.05 significance level using Tukey's HSD.

fluazinam consistently lowered bacterial numbers as was also indicated in the cumulative effects observed (Fig. 1; Table 2).

Fluorescent Pseudomonads. Fluorescent pseudomonads were negatively impacted by fluxapyroxad applications in 2013 when compared with the nontreated control, but it should be noted that the only treatment with similar mean CFUs to the nontreated control was chlorothalonil (Fig. 1). Midway through the 2013 growing season, fluorescent pseudomonads saw a significant decline in response to fluxapyroxad applications (Fig. 2; Table 1). In 2014, fluorescent pseudomonads were not impacted by any fungicide application when compared with the nontreated control (Table 2). Populations of fluorescent pseudomonads were much lower in 2014 than 2013, which may have impacted our ability to detect differences between fungicide treatments in 2014.

General Population Levels. In 2013, phyllosphere populations in the nontreated controls averaged $8 \times 10^{4}, 7 \times 10^{5}, 3 \times 10^{5}$, and $1 \times 10^{6} \mathrm{CFUs} / \mathrm{g}$ tissue for actinomycetes, general bacteria, fungi, and fluorescent pseudomonads respectively. In 2014, phyllosphere populations in the nontreated controls averaged $3 \times 10^{7}$, $2 \times 10^{8}, 6 \times 10^{5}$, and $4 \times 10^{1} \mathrm{CFUs} / \mathrm{g}$ tissue for actinomycetes, general bacteria, fungi, and fluorescent pseudomonads, respectively. Over the course of the 2014 growing season, populations of fungi and actinomycetes appeared to be the most varied, but mean differences show that significant differences were similar across organismal groups, with the exception of fluorescent pseudomonads (Table 2).

Interestingly, our population sizes for bacteria and fungi were similar to populations sizes observed in studies of soil bacterial and fungal populations in soil of turfgrass systems. In newly established bermudagrass (Cynodon dactylon L.) soccer and baseball fields, bacterial populations numbers were between $3.5 \times 10^{7}$ and $6.3 \times$ $10^{7}$ CFUs per gram of soil (Zuberer 2012). Fungal populations were also similar in Zuberer's (2012) findings of populations from $3.6 \times$ $10^{4}$ to $8 \times 10^{4}$ CFUs per gram of soil versus our populations between $3 \times 10^{5}$ and $6 \times 10^{5}$ per gram of tissue. These similarities between our population sizes and turfgrass soil microbial population sizes may be attributed to the close proximity of turfgrass leaves to the soil surface, but additional research is needed to better understand microbial population differences on turfgrass foliage in comparison with the rhizosphere and bulk soil.

Despite minimal effects seen cumulatively across the growing season (Fig. 1), fungicidal effects were observed when comparing organismal groups on individual sample dates (Table 1 and 2; Fig. 2). This observation may be due to microbial populations rebounding before repeated fungicide applications were made. Other than an initial decrease in fungal populations, which returned to levels similar to the nontreated control, from folpet applications between 7 and 14 days post application, there was no significant difference between the control and 
Actinomycetes
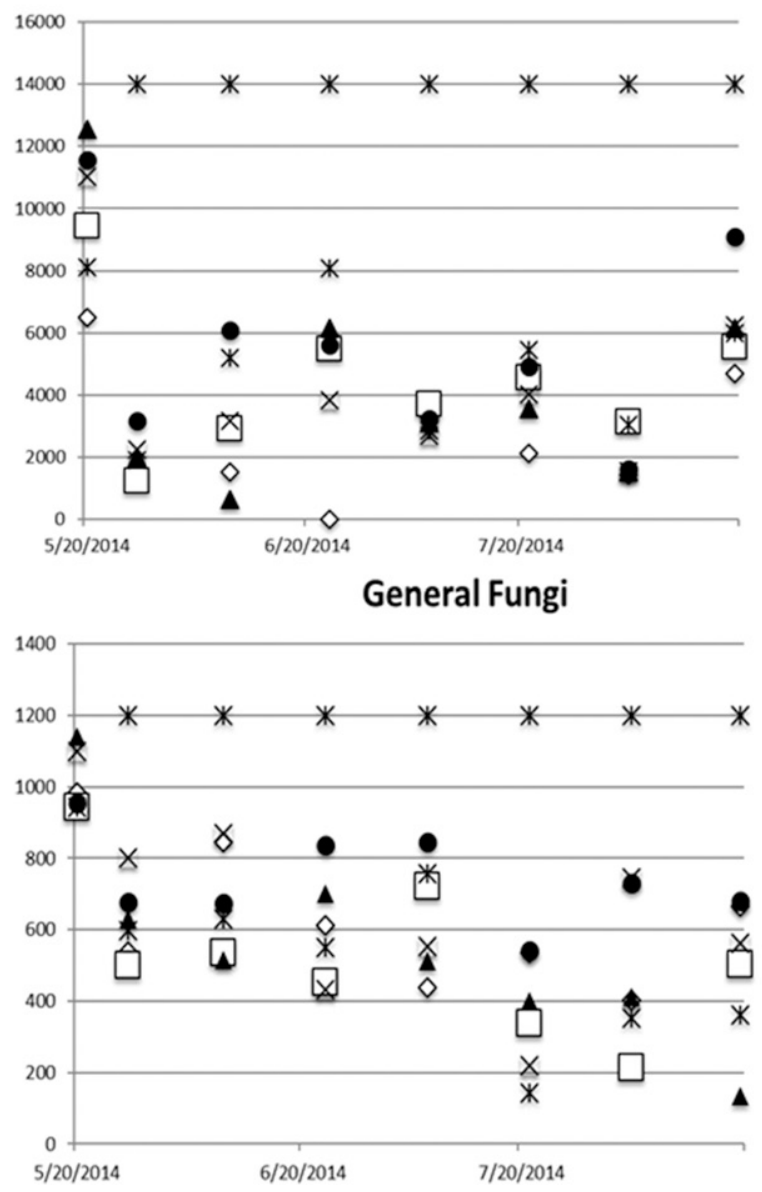

General Bacteria

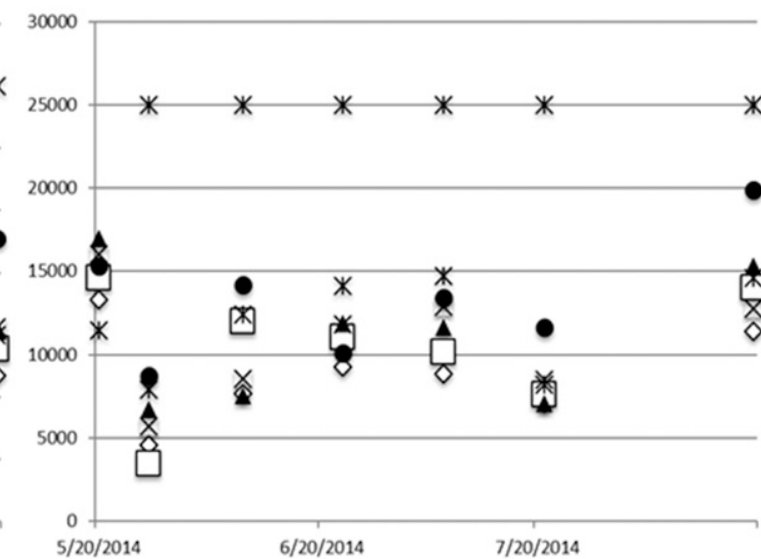

Fluorescent Pseudomonads 2013

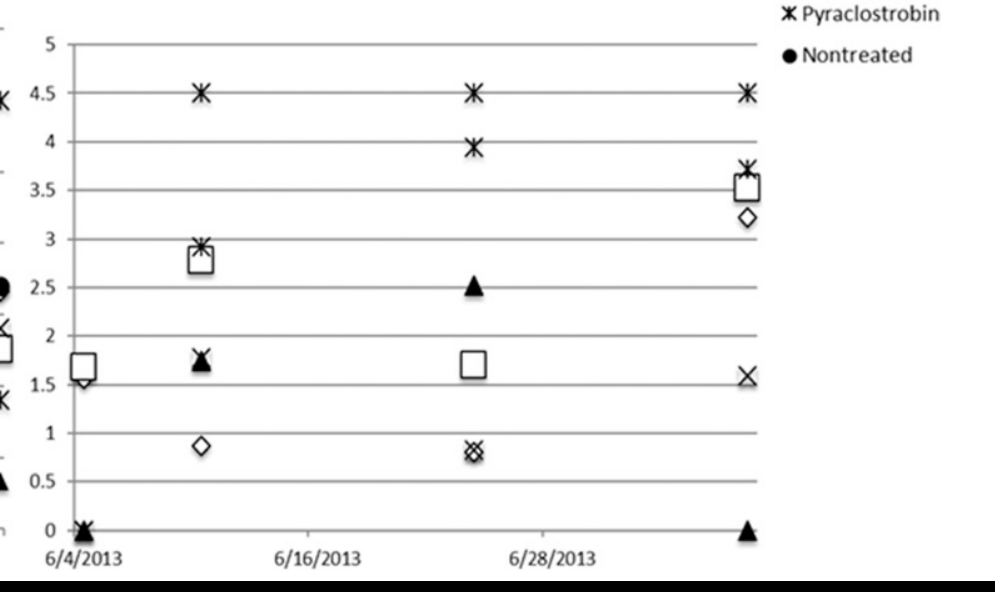

$\diamond$ Fluazinam $\square$ Chlorothalonil A Fluxapyroxad $X$ Fosetyl-Al * Pyraclostrobin

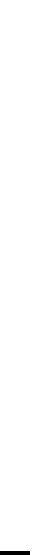

\section{FIGURE 2}

Impact of fungicides applied to a creeping bentgrass putting green on microbial populations throughout the 2014 growing season for actinomycetes, fungi, and general bacteria and the 2013 growing season for fluorescent pseudomonads. * indicates dates on which significant differences were observed at the 0.05 level.

\begin{tabular}{|c|c|c|c|c|c|c|c|c|c|c|c|c|}
\hline \multirow[b]{3}{*}{ Treatment } & \multirow{2}{*}{\multicolumn{6}{|c|}{$\begin{array}{l}\text { TABLE } 1 \\
\text { eparations as affect } \\
\text { General bacteria }\end{array}$}} & \multirow{2}{*}{\multicolumn{3}{|c|}{ Fungi }} & \multirow{2}{*}{\multicolumn{3}{|c|}{$\begin{array}{c}\text { Fluorescent } \\
\text { pseudomonads }\end{array}$}} \\
\hline & & & & & & & & & & & & \\
\hline & 10 June & 24 June & 8 July & 10 June & 24 June & 8 July & 10 June & 24 June & 8 July & 10 June & 24 June & 8 July \\
\hline Chlorothalonil & $\mathrm{B}^{\mathrm{z}}$ & $\mathrm{C}$ & B & A & A & B & $\mathrm{AB}$ & B & A & A & $\mathrm{BC}$ & A \\
\hline Fluazinam & A & $\mathrm{AB}$ & A & A & $\mathrm{D}$ & $\mathrm{BC}$ & B & $\mathrm{C}$ & A & B & $\mathrm{C}$ & A \\
\hline Control & B & B & B & A & $\mathrm{D}$ & $\mathrm{D}$ & A & A & A & A & A & A \\
\hline
\end{tabular}

${ }^{\mathrm{z}}$ Letters separate treatments based on GLIMMIX LSMEANS. Letters are assigned based on highest values.

fungicide treatments on fungal populations (Atlas et al. 1978). Even when soil fumigants, such as methyl-bromide, were used to sterilize soil, the sterility that was achieved was short-lived; fungal propagules and bacterial spores rebounded in just 2 days following methylbromide applications (Ridge and Theodorou 1972). This research helps illustrate that microbial communities in turfgrass are resilient to changes and can recover quickly from external influences.

Previous research examining fungicide adsorption to leaves showed that triadimefon, metalaxyl, and vinclozilin all declined to around $10 \%$ extractability from leaves $48 \mathrm{~h}$ after application (Sigler et al. 2003). Adding to these findings, work by Latin (2006) indicated that efficacy of chlorothalonil, iprodione, propiconazole, and thiophanate-methyl was reduced by $50 \%$ by 6.1 to 9.5 days using a first-order decay model, and 10.6 to 15.2 days using a simple polynomial model. Koch and Kerns (2015) showed that as temperature increased, persistence of the fungicides on leaves decreased; chlorothalonil showed a half-life of 9.5 days and 4.0 days at 10 and $30^{\circ} \mathrm{C}$ respectively, while iprodione showed a more dramatic decline across temperatures with a half-life of 51.2 days and 4 days at 10 and $30^{\circ} \mathrm{C}$, respectively. Rapid adsorption to leaves, the quick decline of 
Microbial populations (2014) mean separations as affected by fungicide treatment at each sample date

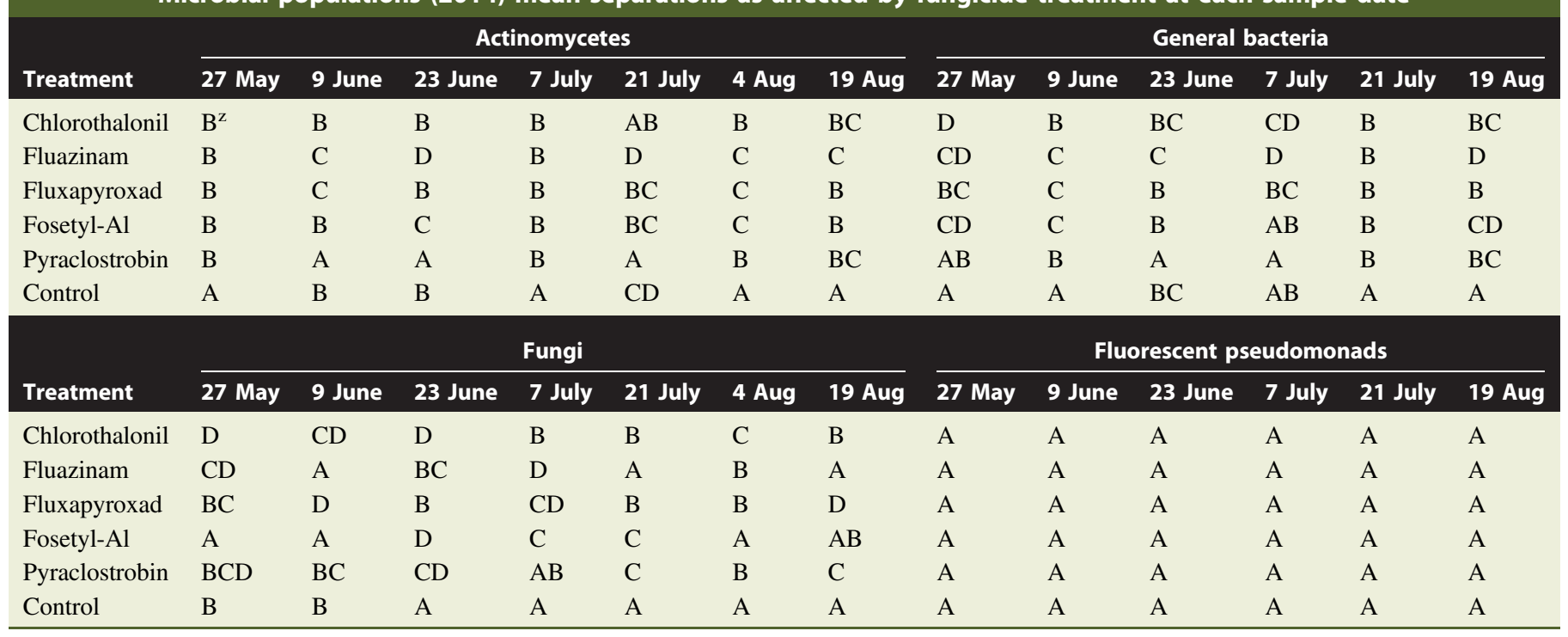

${ }^{\mathrm{z}}$ Letters separate treatments based on GLIMMIX LSMEANS. Letters are assigned based on highest values.

fungicide efficacy, and average temperatures above $30^{\circ} \mathrm{C}$ during our study may have impacted our ability to detect microbial population shifts from fungicide applications at five days post fungicide application. Due to the quick degradation of fungicides, it is also possible that the 14-day application interval, a typical interval for golf course applications, provides enough time for the fungicide to dissipate prior to another application.

Despite claims of pesticides, especially fungicides sterilizing microbial communities, another study like ours was not able to detect differences in total fungi or total bacteria impacted through repeated fungicide applications (Harman et al. 2006). Similarly, Smiley and Craven (1979) also observed that collective microbial groups were often impacted less than individual species from individual and combination fungicide products. Using culture based methods, Siegel (1975) did observe that applications of captan decreased populations of fungi and actinomycetes, while bacterial populations were unaffected. While older chemistries (i.e., heavy metal compounds) were previously shown to impact microbial communities, higher concentrations were necessary to cause an effect. For nematode trapping fungi, cadmium concentrations below $50 \mu \mathrm{g} / \mathrm{ml}$ only inhibited growth, while zinc and lead concentrations needed to pass $50 \mu \mathrm{g} / \mathrm{ml}$ (Rosenzweig and Pramer 1980). Additionally, it was shown that actinomycetes, bacteria, and fungi varied at a species level to cadmium concentrations (Babich and Stotzky 1977). Microbial communities appear to be resilient when subjected to chemical applications, even heavy metals, which are not as selective compared with current fungicides (Nies 1999).

In our study during 2014, major reductions in total phyllosphere populations occurred on 27 May, while actinomycetes and fungi were greatly reduced again on 22 July. It is important to note that weather fluctuations across the season (i.e., temperature and rainfall) seemed to impact microbial populations and additional research is needed to explain the impact of environment on microbes in the turfgrass phyllosphere (data not shown). Five days prior to baseline samples taken in 2014, a rain event of $12.7 \mathrm{~cm}$ with average temperatures around $18^{\circ} \mathrm{C}$ for the month, which was then followed by a period of low precipitation and increasing temperatures (data not shown). This may help explain why microbial populations were so high at the initial sample followed by a drop in all microbial populations across all treatments including the control. Microbial populations rose again across all treatments including the control several other times throughout the trial. All population increases were preceded by rainfall events. Andrews and Kenerley (1978) observed a similar phenomenon in which the first year of their experiment showed a 100- to 1000 -fold reduction following fungicide applications, but in the following year the decrease from fungicide applications was not as pronounced, at around only 50-fold. The authors believe this change in reductions to be due to weather, as the first year had less rainfall than the second (Andrews and Kenerley 1978).

Future research to incorporate next-generation sequencing technologies will benefit our ability to detect differences in entire microbial communities. Culture-independent methods are needed since the culturable microbial communities only represent a small portion of the total microbial communities present (Alexander 2005). In the lettuce phyllosphere, Rastogi et al. (2010) found that, even after accounting for multiple gene copies, between 0.1 and $8.4 \%$ of the bacteria enumerated from qPCR grew on agar media. While culture-dependent methods can give a glimpse into what is transpiring in the microflora, incorporation of next-generation sequencing technologies will provide a highresolution snapshot of changes in individual genera or species.

Based on our research, nontarget microbial impacts as a result of fungicides may be best assessed at individual dates, rather than cumulative across the growing season. Although there were fluctuations in microbial populations, populations seemed to rebound and were also subject to weather impacts on individual microbial groups. From a culture-based perspective, these findings indicate that fungicides do not have a very large impact on microbial communities and that microbial communities are rather robust with respect to fungicide applications. Future research incorporating newer sampling technologies will provide more insight into microbial populations residing in turfgrass ecosystems.

\section{Acknowledgments}

The authors would like to thank the staff of the Lake Wheeler Turfgrass Research Facility for maintenance of the research plots. We would also like to thank Dr. Consuelo Arellano for her assistance in statistical analysis of the data. Funding provided by the Kelman Scholars Program of the Department of Plant Pathology at North Carolina State University. 


\section{Literature Cited}

Alexander, D. B. 2005. Bacteria and archaea. Pages 101-139 in: Principles and Applications of Soil Microbiology, 2nd Ed., D. M. Sylvia, J. J. Fuhrmann, P. G. Hartel, and D. A. Zuberer, eds. Pearson Prentice Hall, Upper Saddle River, NJ.

Alexander, M. 1969. Microbial degradation and biological effects of pesticides in soil. Pages 209-240 in: Soil Biology Reviews of Research. UNESCO, Rome.

Alexander, M. 1977. Introduction to Soil Microbiology, 2nd Ed. Wiley, New York, NY.

Andrews, J. H., and Kenerley, C. M. 1978. The effects of a pesticide program on non-target epiphytic microbial populations of apple leaves. Can. J. Microbiol. 24:1058-1072.

Atlas, R. M., Pramer, D., and Bartha, R. 1978. Assessment of pesticide effects on non-target soil microorganisms. Soil Biol. Biochem. 10:231-239.

Babich, H., and Stotzky, G. 1977. Sensitivity of various bacteria, including actinomycetes, and fungi to cadmium and the influence of $\mathrm{pH}$ on sensitivity. Appl. Environ. Microbiol. 33:681-695.

Buck, J. W., and Burpee, L. L. 2002. The effects of fungicides on the phylloplane yeast populations of creeping bentgrass. Can. J. Microbiol. 48:522-529.

Clarke, B. B., White, J. F., Hurley, R. H., Torres, M. S., Sun, S., and Huff, D. R. 2006. Endophyte-mediated suppression of dollar spot disease in fine fescues. Plant Dis. 90:994-998.

Giordano, P. R., Chaves, A. M., Mitkowski, N. A., and Vargas, J. M. 2012. Identification, characterization, and distribution of Acidivorax avenae subsp. avenae associated with creeping bentgrass etiolation and decline. Plant Dis. 96:1736-1742.

Harman, G. E., Nelson, E. B., and Ondik, K. L. 2006. Non-target effects of fungicide applications on microbial populations of putting greens. USGA Green Sec. Rec. 44:9-12.

Jacobsen, C. S., and Hjelms $\varnothing$, M. H. 2014. Agricultural soils, pesticides, and microbial diversity. Curr. Opin. Biotechnol. 27:15-20.

Koch, P. L., and Kerns, J. P. 2015. Temperature influences persistence of chlorothalonil and iprodione on creeping bentgrass foliage. Plant Health Prog. 16:107-112.

Latin, R. 2006. Residual efficacy of fungicides for control of dollar spot on creeping bentgrass. Plant Dis. 90:571-575.

Mazzola, M. 2002. Mechanisms of natural soil suppressiveness to soilborne diseases. Antonie van Leeuwenhoek 81:557-564.
Mazzola, M. 2004. Assessment and management of soil microbial community structure for disease suppression. Annu. Rev. Phytopathol. 42:35-59.

McCallan, S. E., and Miller, L. P. 1958. Innate toxicity of fungicides. Adv. Pest Control Res. 2:107-134.

Nies, D. H. 1999. Microbial heavy-metal resistance. Appl. Microbiol. Biotechnol. 51:730-750.

Pieterse, C. M., van Wees, S. C., Hoffland, E., van Pelt, J. A., and van Loon, L. C. 1996. Systemic resistance in Arabidopsis induced by biocontrol bacteria is independent of salicyclic acid accumulation and pathogenesis-related gene expression. Plant Cell 8:1225-1237.

Rastogi, G., Tech, J. J., Coaker, G. L., and Leveau, J. H. J. 2010. A PCR-based toolbox for the culture-independent quantification of total bacterial abundances in plant environments. J. Microbiol. Methods 83:127-132.

Ridge, E. H., and Theodorou, C. 1972. The effect of soil fumigation on microbial recolonization and mycorrhizal infection. Soil Biol. Biochem. 4:295-305.

Roberts, J. A., Tredway, L., and Ritchie, D. F. 2014. First report of Xanthomonas translucens causing etiolation on creeping bentgrass turf in Illinois, Kentucky, and North Carolina. Plant Dis. 98:839.

Rosenzweig, W. D., and Pramer, D. 1980. Influence of cadmium, zinc, and lead on growth, trap formation, and collagenase activity of nematode-trapping fungi. Appl. Environ. Microbiol. 40:694-696.

Siegel, M. R. 1975. Benomyl-soil microbial interactions. Phytopathology 65: 219-220.

Sigler, W. V., Reicher, Z., Throssell, C., Bischoff, M., and Turco, R. F. 2003. Sorption and degradation of selected fungicides in the turfgrass canopy. Water Air Soil Pollut. 142:311-326.

Smiley, R. N., and Craven, M. M. 1979. Microflora of turfgrass treated with fungicides. Soil Biol. Biochem. 11:349-353.

Van der Ent, S., Van Wees, S. C. M., and Pieterse, C. M. J. 2009. Jasmonate signaling in plant interactions with resistance-inducing beneficial microbes. Phytochemistry 70:1581-1588.

van Loon, L. C., Bakker, P. A. H. M., and Pieterse, C. M. J. 1998. Systemic resistance induced by rhizosphere bacteria. Annu. Rev. Phytopathol. 36: 453-483.

White, J. F., Jr., Crawford, H., Torres, M. S., Mattera, R., Irizarry, I., and Bergen, M. 2012. A proposed mechanism for nitrogen acquisition by grass seedlings through oxidation of symbiotic bacteria. Symbiosis 57:161-171.

Zuberer, D. 2012. Soil microbes: Some practical perspectives for turfgrass systems. USGA Green Sec. Rec. 50:1-5. 